\title{
Nutrients Use Efficiency and Uptake Characteristics of Panicum virgatum for Fodder Production
}

\author{
Kyriakos Giannoulis ${ }^{1}$, Dimitrios Bartzialis ${ }^{1}$, Elpiniki Skoufogianni ${ }^{1} \&$ Nicholaos Danalatos $^{1}$ \\ ${ }^{1}$ Department of Agriculture, Crop Production and Rural Environment, University of Thessaly, Thessaly, Greece \\ Correspondence: Kyriakos Giannoulis, Department of Agriculture, Crop Production and Rural Environment, \\ University of Thessaly, Thessaly, Greece. E-mail: kyriakos.giannoulis@gmail.com
}

Received: December 2, 2016

Accepted: January 19, $2017 \quad$ Online Published: February 15, 2017

doi:10.5539/jas.v9n3p233

URL: http://dx.doi.org/10.5539/jas.v9n3p233

\begin{abstract}
Panicum virgatum could produce cattle feed with lower costs due to the low input requirements and its perennial nature. Dry biomass yield vs. N-P-K nutrient uptake relations as well as the N-mineralization and the $\mathrm{N}$-fertilization recovery fraction for Panicum virgatum (cv. Alamo) were determined under field conditions for four $\mathrm{N}$-fertilization $\left(0,80,160\right.$ and $\left.240 \mathrm{~kg} \mathrm{ha}^{-1}\right)$ and two irrigation levels $(0$ and $250 \mathrm{~mm})$, on two soils in central Greece with rather different moisture status. It was found that the dry fodder yield on the aquic soil may reach 14 $\mathrm{t} \mathrm{ha}^{-1}$ using supplemental irrigation; while on the xeric soil a lower yield of 9-10 $\mathrm{t} \mathrm{ha}^{-1}$ may be produced only under supplemental irrigation. Moreover, the average N, P and K concentration was $1.3 \%, 0.14 \%$ and $1.3 \%$ in leaves, and $0.5 \%, 0.85 \%$, and $1.5 \%$ in stems, respectively, showing the very low crop requirements. Furthermore, linear biomass yield-nutrient uptake relationships were found with high $\mathrm{R}^{2}$, pointing to nutrient use efficiency of 132 and $75 \mathrm{~kg} \mathrm{~kg}^{-1}$, for $\mathrm{N}$ and $\mathrm{K}$ respectively. The base $\mathrm{N}$-uptake ranged from $71-74 \mathrm{~kg} \mathrm{ha}^{-1}$ on the aquic to $60 \mathrm{~kg}$ $\mathrm{ha}^{-1}$ or less on the xeric soil. Finally, it was found that N-recovery fraction was $20 \%$ on the aquic soil and lower on the xeric. Therefore, it could be conclude that Panicum virgatum seems to be a very promising crop for fodder production and its introduction in land use systems (especially on aquic soils of similar environments) should be taken into consideration.
\end{abstract}

Keywords: N-P-K-uptake, fodder, switchgrass, NUE, base uptake

\section{Introduction}

The economical crisis, especially in Mediterranean territory caused many problems. The increasing demand for food, energy and fiber products has faced agriculture during the last decade. However, adaptation poses challenges for the integration of environmental and socio-cultural services into agricultural production. One of the main problems is the increased annually costs for fodder production such as seeds, fertilizers, pesticides, fuels etc., which leads to the increased animal feed price. On the other hand, due to the price reduction of milk and meat, livestock shrinks. Therefore, new low-input and perennial crops should be examined for the production of low cost animal feed, which will also be able to assess affine and profit to farmers.

Perennial crops offer a significant opportunity to improve agricultural sustainability through crop diversification, reduced erosion, and improved water quality (Asbjornsen et al., 2013; Tolbert \& Wright, 1998). Due to their perennial nature, these crops make their cultivation desirable on highly erosive land, particularly if they can produce high yields under low inputs (Aertsens et al., 2013; McKendry, 2002).

Panicum virgatum L., well known as switchgrass, is a warm season short-day, C4-perennial crop gaining in popularity as a feedstock production in poor erosive land (Sanderson et al., 2004; McLaughlin \& Walsh 1998). Switchgrass is divided into two ecotypes: a) lowland, with adaptation to wet conditions and low latitudes, and b) upland, with adaptation to drier conditions and higher latitudes (Aurangzaib, 2015; Casler, 2012; Moser \& Vogel, 1995). This crop is particularly characterized by high growth rates (Piscioneri et al., 2001) and a deep rooting system (Liebig et al., 2005) contributing to organic matter accumulation in the soil and thus to carbon sequestration (Ma et al., 2000). At full plant development, the below ground biomass is similar to, or even higher than the aerial biomass (Frank et al., 2004; Ma et al., 2001).

In Mediterranean environments, irrigation might generally be needed to ensure adequate yields. Besides irrigation, fertilization is also important for switchgrass growth, and many authors reported the increasing trend 
of yield over time, indicating the positive cumulative effect of nitrogen dressing (Lemus et al., 2008). However, little information exists on P and K fertilization requirements. Muir et al. (2001) reported the little effect of P application on final yield only in case of biomass production for energy, as the levels of phosphorus concentration in switchgrass tissue decrease considerable at advanced growing stages.

Proper fertilization should be based on soil-crop parameters such as nitrogen mineralization (base uptake), yield-nutrient uptake relations, and fertilization nutrient recovery fraction. Such data are generally absent for switchgrass, especially growing under Mediterranean environmental conditions for fodder production.

Consequently, this study determinates relations under field conditions in a typical Mediterranean region such as the Thessaly plain which is the greatest lowland formation, and the centre of the Greek agricultural production. It was considered here the promising "Alamo" cultivar for fodder production at two soils with different soil moisture status. The chosen soils were: a) a calcareous, fine-textured, fertile soil, typical for the dry East Thessaly plain (Calcixerollic Xerochrept; United States Department of Agriculture [USDA], 1975), and b) an aquic soil with a fluctuating groundwater table, representing large parts of the meandering West Thessaly plain, having calcareous, alluvial, medium to coarse textured soils (Aquic Xerofluvent; USDA, 1975).

\section{Materials and Methods}

For the purposes of this study two field experiments were established in two different soil-climatic environments, e.g. in Palamas (West Thessaly or Karditsa plain; $39^{\circ} 26^{\prime} \mathrm{N} \& 22^{\circ} 04^{\prime} \mathrm{E}$ ) and in Velestino (East Thessaly or Larisa plain; $\left.39^{\circ} 02^{\prime} \mathrm{N} \& 22^{\circ} 45^{\prime} \mathrm{E}\right)$, central Greece.

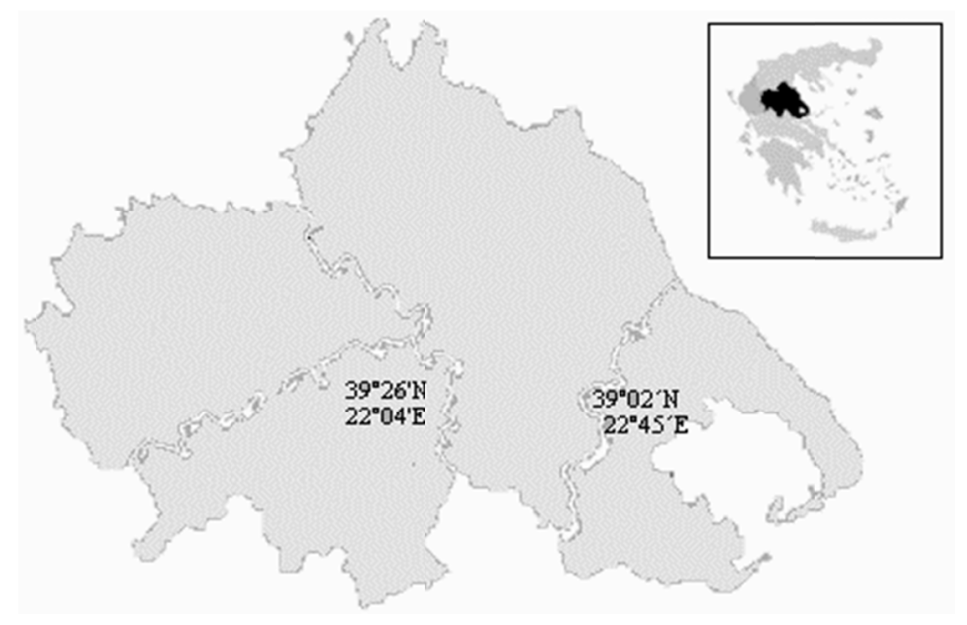

Figure 1. Geographical location coordinates of the field experiments in Thessaly Plain, Greece

Palamas soil is a deep soil, characterized by a groundwater table fluctuating from some $2 \mathrm{~m}$ below the soil surface (receives artificial drainage) in May, to deeper layers later in the summer, and was classified as Aquic Xerofluvent, while Velestino soil was classified as Calcixerollic Xerochrept, according to USDA (1975). Soil characteristics for both sites are presented in Table 1.

Despite its inherent fertility, Palamas's soil has a better top soil structure, is less compacted and allows the formation of a deep rooting system, while Velestino's soil is very dry during the summer months, and rather compacted, hindering the formation of a deep rooting system. 
Table 1. Soil characteristics of the studied fields in depth of $0-40 \mathrm{~cm}$

\begin{tabular}{|c|c|c|c|c|c|c|c|c|c|}
\hline & \multirow{2}{*}{$\mathrm{pH}$} & \multicolumn{3}{|c|}{ Composition } & \multirow{2}{*}{$\begin{array}{l}\text { Organic } \\
\text { Matter } \\
(\%)\end{array}$} & \multirow{2}{*}{$\begin{array}{l}\text { Electrical } \\
\text { conductivity } \\
\left(\mu \mathrm{S} \mathrm{cm}^{-1}\right)\end{array}$} & \multirow{2}{*}{$\begin{array}{l}\text { Total N } \\
(\%)\end{array}$} & \multirow{2}{*}{$\begin{array}{l}\text { Available P } \\
\left(\mathrm{mg} \mathrm{kg}^{-1}\right)\end{array}$} & \multirow{2}{*}{$\begin{array}{l}\text { Available K } \\
\left(\mathrm{mg} \mathrm{kg}^{-1}\right)\end{array}$} \\
\hline & & Sand (\%) & Silt (\%) & Clay (\%) & & & & & \\
\hline \multicolumn{10}{|l|}{ Palamas } \\
\hline $0-10 \mathrm{~cm}$ & 8.3 & 37 & 51 & 12 & 0.9 & 225 & 0.7 & 10 & 190 \\
\hline $10-40 \mathrm{~cm}$ & 8.3 & 45 & 43 & 12 & 0.9 & 216 & 0.5 & 10 & 191 \\
\hline \multicolumn{10}{|l|}{ Velestino } \\
\hline $0-10 \mathrm{~cm}$ & 8.3 & 21 & 41 & 38 & 2.7 & 475 & 4.68 & 8 & 254 \\
\hline $10-40 \mathrm{~cm}$ & 8.1 & 19 & 39 & 42 & 2.3 & 604 & 1.04 & 4 & 178 \\
\hline
\end{tabular}

Switchgrass (Panicum virgatum) cv. Alamo (lowland ecotype supplied from Colorado USA), was sown in June 2009 , using a modern cereal seeding machine, applying $7 \mathrm{~kg}$ seed ha ${ }^{-1}$ at a row distance of $12.5 \mathrm{~cm}$. This is slightly more than advised for ideal crop establishment [5.7 $\mathrm{kg} \mathrm{ha}^{-1}$; (Elbersen et al., 2004)]. It should be noted that seeding amounts in a range of 4.5-11.2 $\mathrm{kg} \mathrm{ha}^{-1}$ did not affect biomass yield after the first year of establishment (West \& Kincer, 2011).

A $2 \times 4$ split-plot experimental design was used with four replications (blocks) and eight plots per replication (8 $\times 4=32$ plots). Irrigation comprised the main factor $[\mathrm{I} 1=0 \mathrm{~mm}$ (rainfed), $\mathrm{I} 2=250 \mathrm{~mm}]$, and nitrogen dressing comprised the sub-factor $\left(\mathrm{N} 1=0, \mathrm{~N} 2=80, \mathrm{~N} 3=160\right.$ and $\left.\mathrm{N} 4=240 \mathrm{~kg} \mathrm{~N} \mathrm{ha}^{-1}\right)$. Plot size was $48 \mathrm{~m}^{2}(6 \mathrm{~m}$ width $\times$ $8 \mathrm{~m}$ length). It should be noticed that $250 \mathrm{~mm}$ comprise only supplemental irrigation (estimated at about half of the potential evapotranspiration deficit in an average year in soils without any capillary rice).

The crop was sampled twice: the first sampling was conducted when the plants reached $1 \mathrm{~m}$ in height (92 days after emergence - DAE, stage of four leaves). The second sampling took place upon seed maturation (approximately $190 \mathrm{DAE}$ ). In each (destructive) sampling, $1 \mathrm{~m}^{2}$ in every plot was harvested, and the plants were divided into leaves, stems and storage organs, which were weighed and oven-dried at $65{ }^{\circ} \mathrm{C}$ until equal weights. The dry samples were chopped and grounded. Nitrogen content in the various plant organs (leaves, stems, and storage organs) was measured using the standard Kjeldhal method (Nelson \& Sommers, 1973), while the total phosphorus and potassium contents were determined with the of dry combustion method, using a spectrophotometer (P) and flame photometry (K) (Jones \& Case, 1990). Then, dry matter per plant organ was multiplied by the respective N-P-K concentration to calculate the final nutrient removal (uptake) of the sampled biomass in the mentioned growth stages.

It should be noticed that proper nutrient uptake determinations require at least one extra year of field experimentation, with plots having the same fertilization levels placed exactly at the same position, to minimize any residual effect from previous fertilization. This was the case in both field experiments here. The presented data correspond to 2011 and 2012 experimental years, where switchgrass cultivation was already in the $3^{\text {rd }}$ and $4^{\text {th }}$ growing periods.

In this paper, only biomass data of the first sampling are further analyzed, as they refer to the use of switchgrass biomass for fodder production.

\section{Results and Discussion}

\subsection{Weather Conditions}

The study areas are characterized by a typical Mediterranean climate with cold humid winters and hot-dry summers. In particular, the average air temperature ranged from $25.4{ }^{\circ} \mathrm{C}$ (at Velestino) to $26.5{ }^{\circ} \mathrm{C}$ (at Palamas) during the summer 2011. Precipitation in the same period ranged from $295 \mathrm{~mm}$ at Palamas, to only $203 \mathrm{~mm}$ at Velestino area. The following year (2012) was exceptionally warm with air temperature ranging from $27.5^{\circ} \mathrm{C}$ at Velestino to $31^{\circ} \mathrm{C}$ at Palamas. Similar precipitation with the previous year (2011) was recorded in $2012(305 \mathrm{~mm}$ at Palamas, to $197 \mathrm{~mm}$ at Velestino [Figure 2]). Apparently, the most adverse conditions for switchgrass growth prevailed at the dry Velestino site in the warm year 2012, whereas much greater growth rates are expected at the aquic Palamas soil especially in the cooler year 2011. 


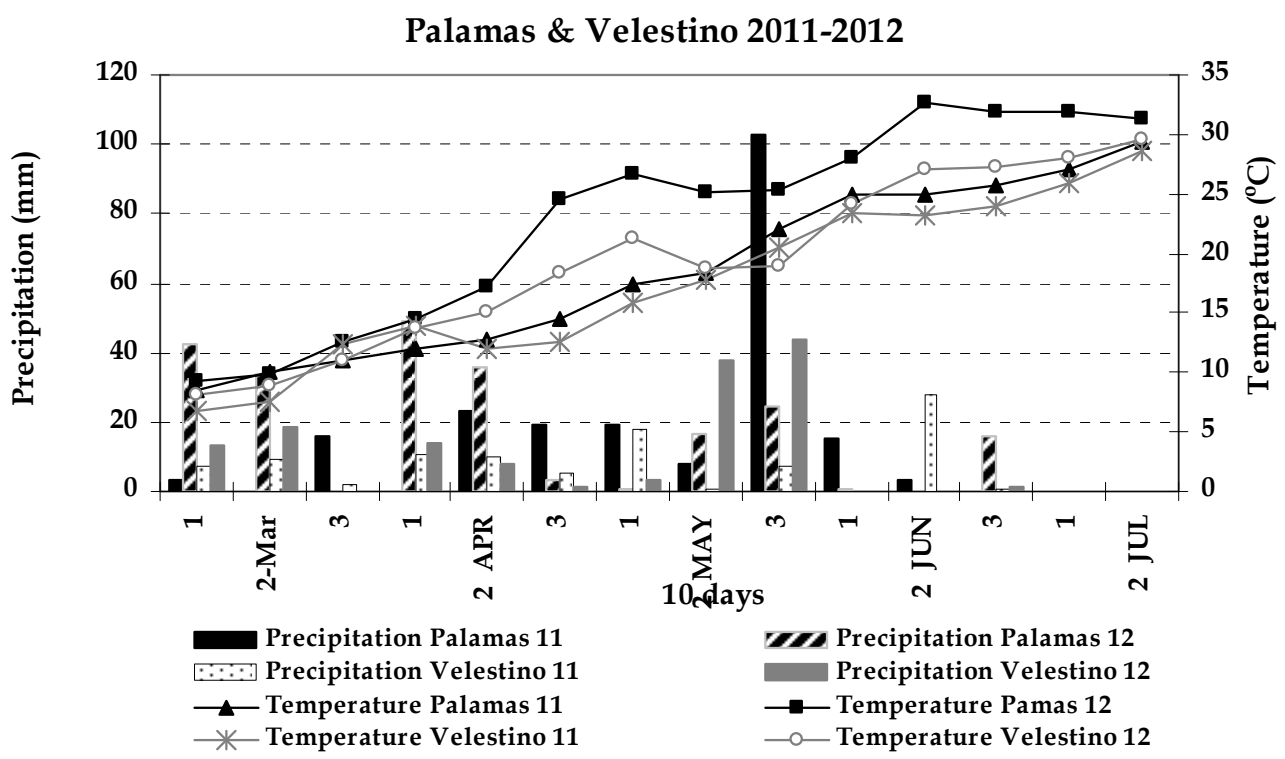

Figure 2. Temperature and precipitation (10-days mean values) occurring in both studied sites during the growing periods of switchgrass in 2011 and 2012

\subsection{Fodder Yield}

Table 2 shows the considerable variation in the dry biomass of switchgrass among the different soil-environmental conditions and irrigation/fertilization inputs.

Table 2. Switchgrass dry weight of leaves and stems $\left(\mathrm{t} \mathrm{ha}^{-1}\right)$ as affected by 2 irrigation (I1, I2), and 4 $\mathrm{N}$-fertilization levels (N1, N2, N3, and N4)

\begin{tabular}{|c|c|c|c|c|c|c|}
\hline & \multicolumn{3}{|c|}{ Dry Weight of Leaves } & \multicolumn{3}{|c|}{ Dry Weight of Stems } \\
\hline & Palamas 2011 & Palamas 2012 & Velestino 2012 & Palamas 2011 & Palamas 2012 & Velestino 2012 \\
\hline \multicolumn{7}{|c|}{ Irrigation level } \\
\hline I1 & 2.98 & 3.49 & 2.68 & $4.61 \mathrm{a}$ & 8.77 & 5.64 \\
\hline I2 & 3.25 & 3.90 & 2.99 & $5.86 \mathrm{~b}$ & 9.70 & 6.45 \\
\hline LSD & ns & ns & ns & 0.584 & Ns & ns \\
\hline \multicolumn{7}{|c|}{$N$-Fertilization level } \\
\hline N1 & $2.46 \mathrm{a}$ & $3.28 \mathrm{ab}$ & 2.92 & $3.86 \mathrm{a}$ & $8.07 \mathrm{a}$ & 6.43 \\
\hline $\mathrm{N} 2$ & $2.89 \mathrm{~b}$ & $3.09 \mathrm{a}$ & 2.81 & $4.92 \mathrm{~b}$ & $7.88 \mathrm{a}$ & 5.89 \\
\hline $\mathrm{N} 3$ & $3.51 \mathrm{c}$ & $4.28 \mathrm{c}$ & 2.77 & $6.26 \mathrm{~d}$ & $10.42 \mathrm{~b}$ & 5.62 \\
\hline $\mathrm{N} 4$ & $3.60 \mathrm{~d}$ & $4.15 \mathrm{bc}$ & 2.84 & $5.90 \mathrm{c}$ & $10.55 \mathrm{~b}$ & 6.25 \\
\hline LSD & 0.050 & 0.991 & ns & 0.179 & 2.05 & ns \\
\hline CV $(\%)$ & 3.2 & 25.5 & 9.2 & 3.3 & 21.1 & 13.4 \\
\hline
\end{tabular}

Note. Duncan criterion: a, b.

\subsubsection{Aquic Soils}

The maximum yield reached $14 \mathrm{tha}^{-1}$ for the irrigated and fertilized treatments on the aquic soil in the "warmer" year 2012, while in the "cooler" year 2011, the irrigated and fertilized crop exceeded a yield of $9 \mathrm{t} \mathrm{ha}{ }^{-1}$.

Such yields seem to be great for fodder production especially if there is the possibility of a second and a third cut during the same growing year. Compared with dry matter yields of maize or maize-legume mixtures [about 9-10 $\mathrm{t} \mathrm{ha}^{-1}$; (Ibrahim et al., 2014)], switchgrass harvested yield is $40 \%$ higher, which will lead at an increased farmer income considering the perennial crop nature and therefore the decreased annual establishment costs. Comparing 
with other fodder crops like oat (Avena sativa) which could produce up to $12 \mathrm{t} \mathrm{ha}^{-1}$, and alfalfa that produces an average annual yield of 9-15 $\mathrm{t} \mathrm{ha}^{-1}$ [(Tie-jun et al., 2014); but alfalfa needs 4-5 harvests per year] switchgrass seems to be an interest cultivation for higher fodder yield. Considerable yields may be obtainable on aquic soils without irrigation, reaching $12 \mathrm{t} \mathrm{ha}^{-1}$ (Table 2), depending on weather conditions. This is apparently due to the positive effect of the groundwater table and the deep rooting system of the crop.

On the other hand, N-fertilization showed a slight positive effect on fodder yield (Table 2) with the unfertilized plots performing a substantial yield of $6.3 \mathrm{t} \mathrm{ha}^{-1}$ in 2011, to $11.4 \mathrm{t} \mathrm{ha}^{-1}$ in 2012. The full $\mathrm{N}$-fertilized plots produced a higher yield in $2012\left(14.7 \mathrm{t} \mathrm{ha}^{-1}\right)$, while in 2011 remained in lower levels $\left(9.5 \mathrm{t} \mathrm{ha}^{-1}\right)$.

These data are very important signaling the possibility of growing switchgrass for fodder production in aquic soils in Greece and more generally in Mediterranean region, under zero or minimum inputs of irrigation and low inputs of $\mathrm{N}$-fertilization.

\subsubsection{Typical (Xeric) Soils}

The irrigation effect was not evident neither on the drier soil (Velestino), reflected by a $10 \%$ increase in dry biomass yield upon irrigation; rate almost the same with the aquic soil (Palamas). This was due to the lower air temperature in comparison with Palamas site (especially in 2012) and the presence rainfall albeit at low levels. Therefore, the absence of groundwater table reduces the yield compared with an aquic soil (viz. $9.44 \mathrm{t} \mathrm{ha}^{-1}$ instead of 13.67 Table 2), and the effect of capillary rise which is absent, could be attributed to reduced fodder production by about $4 \mathrm{tha}^{-1}$.

Apparently, such low biomass yields remove less amounts of nitrogen from soil, so that only modest effects of $\mathrm{N}$-fertilization should be expected in such soils.

\subsection{Nutrient Concentration in the Plant Tissue}

The data on N-P-K concentration measured per plant organ for all treatments and years are summarized in Table 3. Average values for plant taken into account the dry weight per plant organ are presented in Table 4.

It can be observable that the average $\mathrm{N}$-concentration in plant tissues varies between $1.2-1.4 \%$ in leaves and $0.4-0.6 \%$ in stems, independent on soil type and fertilization treatments. This rate is more than the double $\mathrm{N}$-content in rice leaves $[0.5 \%$; (Abbeddou et al., 2011)] and almost the same with the N-content of rice stems [0.44\%; (Abbeddou et al., 2011)]. The overall N-content in plant ranges between $0.70 \%$ (in the cooler year 2011) and $0.95 \%$ (in the warmer year 2012) (Table 4). Therefore, protein content of switchgrass straw is $6.25 \%$ with very low needs in nitrogen, confirming that the crop might grow well in less fertile-erosive soils, enabling the rural world to produce cheaper animal feed. In comparison to traditional cereal crops straw [e.g. barley $4.3 \%$, (Vadiveloo, 2000); wheat 3.5\%, oat 4.4\%, (National Research Council, 1996)], switchgrass has higher protein content which is in the rate of pea and lentil straw [6.5\% and 6.4\%, respectively, (NRC, 1996)]. The total $\mathrm{N}$ uptake from switchgrass fodder production is $60 \mathrm{~kg} \mathrm{ha}^{-1}$ in dry soils (Velestino) to $120 \mathrm{~kg} \mathrm{ha}^{-1}$ in aquic soils (Palamas). 
Table 3. N-P-K content (\%) in dry biomass of switchgrass organs as affected by 2 irrigation (I1, I2), and 4 $\mathrm{N}$-fertilization levels (N1, N2, N3 and N4)

\begin{tabular}{|c|c|c|c|c|c|c|}
\hline \multirow{2}{*}{$\%$ content } & \multicolumn{2}{|c|}{ Nitrogen content } & \multicolumn{2}{|c|}{ Phosphorus content } & \multicolumn{2}{|c|}{ Potassium content } \\
\hline & Leaves & Stems & Leaves & Stems & Leaves & Stems \\
\hline \multicolumn{7}{|c|}{ Palamas 2011} \\
\hline \multicolumn{7}{|c|}{ Irrigation level } \\
\hline I1 & 1.176 & 0.392 & 0.147 & 0.104 & 1.135 & 1.835 \\
\hline $\mathrm{I} 2$ & 1.381 & 0.592 & 0.155 & 0.092 & 1.252 & 1.683 \\
\hline $\operatorname{LSD}_{0.05}$ & 0.1605 & ns & ns & ns & ns & $\mathrm{ns}$ \\
\hline \multicolumn{7}{|c|}{ Fertilization level } \\
\hline N1 & 1.134 & 0.406 & 0.125 & 0.092 & 1.056 & 1.768 \\
\hline $\mathrm{N} 2$ & 1.302 & 0.434 & 0.172 & 0.096 & 1.302 & 1.800 \\
\hline N3 & 1.316 & 0.504 & 0.154 & 0.100 & 1.236 & 1.668 \\
\hline N4 & 1.362 & 0.485 & 0.154 & 0.103 & 1.180 & 1.801 \\
\hline $\mathrm{LSD}_{0.05}$ & ns & ns & ns & ns & ns & ns \\
\hline CV $(\%)$ & 5.6 & 19.2 & 11.1 & 19.5 & 13.5 & 5.8 \\
\hline \multicolumn{7}{|c|}{ Palamas 2012} \\
\hline \multicolumn{7}{|c|}{ Irrigation level } \\
\hline I1 & 1.410 & 0.459 & 0.125 & 0.065 & 1.016 & 1.457 \\
\hline $\mathrm{I} 2$ & 1.413 & 0.441 & 0.133 & 0.070 & 1.155 & 1.399 \\
\hline $\mathrm{LSD}_{0.05}$ & ns & ns & ns & $\mathrm{ns}$ & ns & ns \\
\hline \multicolumn{7}{|c|}{ Fertilization level } \\
\hline N1 & 1.435 & 0.380 & 0.130 & 0.074 & 1.133 & 1.437 \\
\hline $\mathrm{N} 2$ & 1.216 & 0.488 & 0.147 & 0.072 & 1.555 & 1.502 \\
\hline N3 & 1.366 & 0.498 & 0.119 & 0.066 & 0.780 & 1.440 \\
\hline N4 & 1.630 & 0.435 & 0.122 & 0.058 & 0.873 & 1.332 \\
\hline $\mathrm{LSD}_{0.05}$ & ns & 0.0570 & ns & ns & ns & ns \\
\hline CV $(\%)$ & 6.0 & 4.0 & 10.4 & 12.5 & 22.0 & 12.2 \\
\hline \multicolumn{7}{|c|}{ Velestino 2012} \\
\hline \multicolumn{7}{|c|}{ Irrigation level } \\
\hline I1 & 1.290 & 0.449 & 0.145 & 0.079 & 1.330 & 1.188 \\
\hline $\mathrm{I} 2$ & 1.484 & 0.507 & 0.160 & 0.082 & 1.416 & 1.148 \\
\hline $\mathrm{LSD}_{0.05}$ & 0.1417 & ns & ns & ns & ns & $\mathrm{ns}$ \\
\hline \multicolumn{7}{|c|}{ Fertilization level } \\
\hline N1 & 1.355 & 0.416 & 0.145 & 0.076 & 1.363 & 1.138 \\
\hline $\mathrm{N} 2$ & 1.363 & 0.455 & 0.152 & 0.069 & 1.466 & 1.198 \\
\hline $\mathrm{N} 3$ & 1.415 & 0.502 & 0.167 & 0.089 & 1.350 & 1.106 \\
\hline N4 & 1.413 & 0.541 & 0.147 & 0.089 & 1.312 & 1.231 \\
\hline $\mathrm{LSD}_{0.05}$ & $\mathrm{~ns}$ & $\mathrm{~ns}$ & $\mathrm{~ns}$ & $\mathrm{~ns}$ & $\mathrm{~ns}$ & $\mathrm{~ns}$ \\
\hline CV (\%) & 4.5 & 17.4 & 16.4 & 13.6 & 4.4 & 11.1 \\
\hline
\end{tabular}

Note. Duncan criterion: a, b.

Similar to nitrogen, phosphorus content varies in different plant organs. Actually, leaves contain $0.13-0.15 \%$ of phosphorus, whereas stems contain only $0.07-0.10 \%$ (Table 3 ) which is almost the same with traditional cereals straw [e.g. barley $0.07 \%$, oat $0.06 \%$, wheat $0.05 \%$, (NRC, 1996)] and lower than pea and lentil straw $(0.19 \%$ and $0.20 \%$, respectively, (NRC, 1996)]. Average phosphorus plant concentration ranges from 0.08 to $0.12 \%$ among the different soils and years (Table 4). Total phosphorus uptake reached $15 \mathrm{~kg} \mathrm{ha}^{-1}$ on aquic soils (Palamas) to 9.4 $\mathrm{kg} \mathrm{ha}^{-1}$ on dry soils (Velestino).

Finally, average Potassium content in plant was 10-15 times greater than phosphorus content and $50-70 \%$ greater than $\mathrm{N}$ concentration, fluctuating between $1.3 \%$ on aquic soils (Palamas site; both years) and $1.5 \%$ on xeric soils 
(Velestino site; both years). These rates are the same with the rate of wheat straw $1.41 \%$ and lower than other straws [e.g. oat $2.53 \%$, barley 2.37 , pea $2.04 \%$, (NRC, 1996)]. Total potassium uptake reached $128 \mathrm{~kg} \mathrm{ha}^{-1}$ in the dry Velestino soil to $160 \mathrm{~kg} \mathrm{ha}^{-1}$ in the aquic Palamas soil.

Table 4. Switchgrass plant tissue N-P-K content (\%) of dry biomass as affected by 2 irrigation (I1, I2), and 4 $\mathrm{N}$-fertilization levels (N1, N2, N3 and N4)

\begin{tabular}{|c|c|c|c|c|c|c|c|c|c|}
\hline \multirow{2}{*}{$\%$ content } & \multicolumn{3}{|c|}{ Palamas 2011} & \multicolumn{3}{|c|}{ Palamas 2012} & \multicolumn{3}{|c|}{ Velestino 2012} \\
\hline & $\mathrm{N}$ & $\mathrm{P}$ & $\mathrm{K}$ & $\mathrm{N}$ & $\mathrm{P}$ & $\mathrm{K}$ & $\mathrm{N}$ & $\mathrm{P}$ & $\mathrm{K}$ \\
\hline \multicolumn{10}{|c|}{ Irrigation level } \\
\hline I1 & 0.729 & 0.082 & 1.332 & 0.892 & 0.116 & 1.294 & 0.684 & 0.111 & 1.543 \\
\hline $\mathrm{I} 2$ & 0.720 & 0.087 & 1.326 & 1.015 & 0.118 & 1.166 & 0.670 & 0.101 & 1.343 \\
\hline $\mathrm{LSD}_{0.05}$ & ns & $\mathrm{ns}$ & ns & ns & ns & ns & ns & ns & ns \\
\hline \multicolumn{10}{|c|}{$N$-Fertilization level } \\
\hline N1 & 0.685 & 0.090 & 1.350 & 0.883 & 0.103 & 1.231 & 0.722 & 0.121 & 1.637 \\
\hline $\mathrm{N} 2$ & 0.692 & 0.093 & 1.513 & 1.004 & 0.132 & 1.354 & 0.786 & 0.118 & 1.518 \\
\hline N3 & 0.750 & 0.081 & 1.248 & 0.998 & 0.119 & 1.268 & 0.783 & 0.120 & 1.588 \\
\hline N4 & 0.770 & 0.076 & 1.204 & 0.929 & 0.113 & 1.067 & 0.418 & 0.065 & 1.029 \\
\hline $\mathrm{LSD}_{0.05}$ & $\mathrm{~ns}$ & ns & $\mathrm{ns}$ & ns & 0.0097 & ns & ns & $\mathrm{ns}$ & ns \\
\hline $\mathrm{CV} \%$ & 3.5 & 9.6 & 9.1 & 5.9 & 2.6 & 15.7 & 29.6 & 21.4 & 19.1 \\
\hline
\end{tabular}

Note. Duncan criterion: a, b.

\subsection{Yield-Nutrient Uptake Relation}

Plotting dry biomass versus nitrogen uptake (the latter calculated as $\sum N_{i}{ }^{*} D_{i}$, where, N: N-P-K content in plant organs and D: dry biomass per plant organ) results in yield-nutrient uptake relation illustrated in Figures 3, 4 and 5.

\subsubsection{Nitrogen}

It can be seen that a linear relationship apply that might explain $89 \%$ of the existing variation $\left(\mathrm{R}^{2}=0.89\right)$, largely independent of environmental conditions (soils, years), and irrigation and fertilization management. Actually, many authors have shown that yield-uptake relation is mostly species/variety dependant. It should be noticed that the slope of yield-uptake relation reflects the Nitrogen Use Efficiency (NUE), which in this case takes a considerably high value, e.g. about $132 \mathrm{~kg} \mathrm{~kg}^{-1}$. This is explained by the low $\mathrm{N}$-concentration in plant (Tables 3 , 4), resulting in a much higher NUE compared with other crops [e.g. wheat $43-55 \mathrm{~kg} \mathrm{~kg}^{-1}$, (Thomason et al., 200); corn $60-70 \mathrm{~kg} \mathrm{~kg}^{-1}$, sunflower, $25-30 \mathrm{~kg} \mathrm{~kg}^{-1}$, (Skoufogianni et al., 2013)] and confirms that switchgrass may successfully grown in less fertile soils and produce appreciable high yields. It can be also observed that all yield-uptake data values in Figure 3 are in the linear part of the curve, denoting proportional growth in all experiments. 


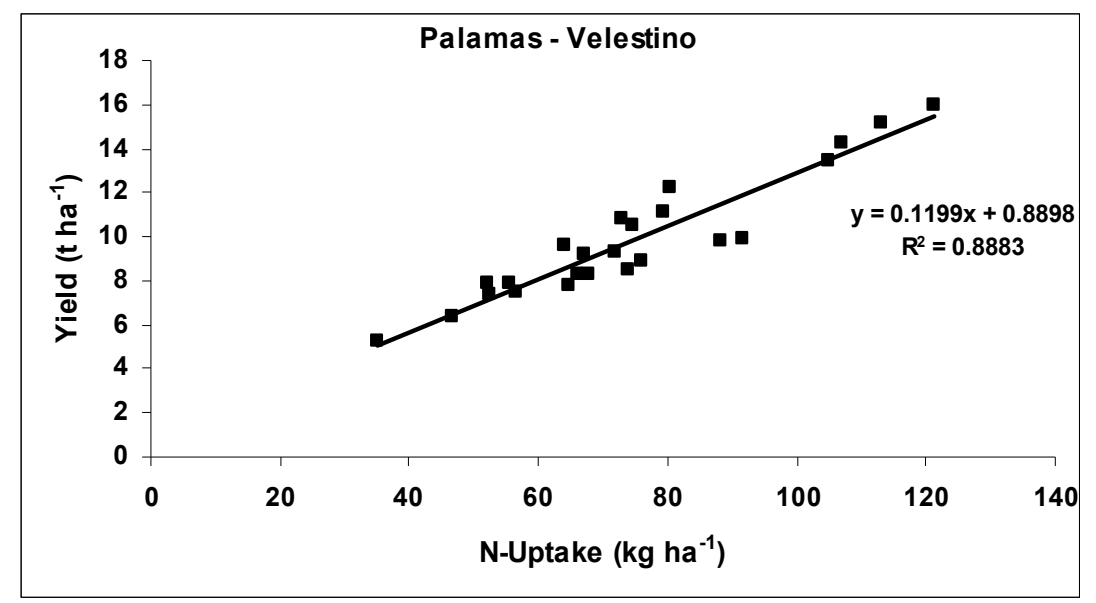

Figure 3. $\mathrm{N}$-uptake $\left(\mathrm{kg} \mathrm{ha}^{-1}\right)$ and dry biomass yield $\left(\mathrm{t} \mathrm{ha}^{-1}\right)$ as affected by 2 irrigation (I1, I2), and 4 $\mathrm{N}$-fertilization levels (N1, N2, N3 and N4), on 2 different soils (Palamas - aquic, Velestino - dry) during 2 growing periods $(2011,2012)$

\subsubsection{Phosphorus and Potassium}

Plotting dry yield versus phosphorus and potassium uptake results in yield-uptake relation for these nutrients in Figures 4 and 5, respectively.

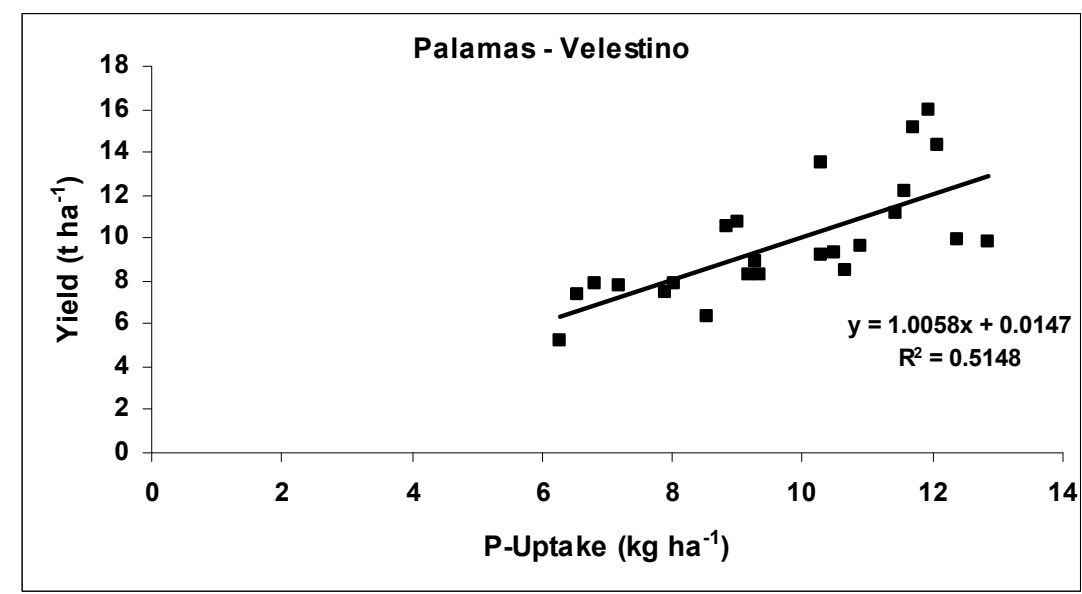

Figure 4. P-uptake $\left(\mathrm{kg} \mathrm{ha}^{-1}\right)$ and dry biomass yield $\left(\mathrm{t} \mathrm{ha}^{-1}\right)$ as affected by 2 irrigation (I1, I2), and $4 \mathrm{~N}$-fertilization levels (N1, N2, N3 and N4), on 2 different soils (Palamas - aquic, Velestino - dry) during 2 growing periods

$(2011,2012)$

It is shown that a linear relationship apply for $\mathrm{K}$ might be explained by $80 \%$ of the existing variation $\left(\mathrm{R}^{2}=0.80\right)$, whereas yield-P uptake relation was not so strong $\left(R^{2}=0.51\right.$, Figure 4). The slope of yield-uptake relation reflects Phosphorus and Potassium Use Efficiency (PUE \& KUE) which takes a considerably high value for P, e.g. about $1027 \mathrm{~kg} \mathrm{~kg}^{-1}$, and about $75 \mathrm{~kg} \mathrm{~kg}^{-1}$ for $\mathrm{K}$. This is explained by the low $\mathrm{P}$ and extremely low $\mathrm{K}$ concentration in switchgrass tissue (Tables 3 , and 4).

The determination of nutrient uptake (N-P-K) is an important and necessary agronomic tool for each crop, and especially for switchgrass cultivation such information is important to define crop fertilization requirements.

Concluding, switchgrass seems to be cultivation of very low nutrient requirements, as per $10 \mathrm{t}$ fodder, $83.4 \mathrm{~kg} \mathrm{~N}$, $9.9 \mathrm{~kg} \mathrm{P}$ and $141.0 \mathrm{~kg} \mathrm{~K}$ may only be removed from soil. 




Figure 5. K-uptake $\left(\mathrm{kg} \mathrm{ha}^{-1}\right)$ and dry biomass yield $\left(\mathrm{t} \mathrm{ha}^{-1}\right)$ as affected by 2 irrigation (I1, I2), and 4 $\mathrm{N}$-fertilization levels (N1, N2, N3 and N4), on 2 different soils (Palamas - aquic, Velestino - dry) during 2 growing periods $(2011,2012)$

\subsection{Nitrogen Uptake-Supply Relation}

\subsubsection{Base Uptake}

Nutrient uptake determined in unfertilized (control) plots, consists base uptake or basic mineralization. The above parameter expresses soil inherent fertility and depends on its conditions - root environment, e.g. effective rooting depth, soil organic carbon content, dry bulk density, $\mathrm{C} / \mathrm{N}$ ratio, soil moisture and temperature, etc. In order to determine the base uptake rate, at least one extra year of field experimentation is needed with zero fertilization plots placed exactly at the same position, so any effect of residual fertilization from previous years is minimized. This was the case at Velestino and Palamas field experiments.

Plotting N-uptake versus $\mathrm{N}$-supply via fertilization (see Figure 6), base uptake is the value in y-axis (zero fertilization). Results show that in 2012 whereas precipitation was in high levels (Figure 2), the base uptake of nitrogen was rather high reaching $74 \mathrm{~kg} \mathrm{ha}^{-1}$, largely independent on irrigation treatment $\left(71-74 \mathrm{~kg} \mathrm{~N} \mathrm{ha}^{-1}\right.$; Figure 6). In the same year, the base uptake on Velestino soil reached $60 \mathrm{~kg} \mathrm{~N} \mathrm{ha}^{-1}$ in irrigated treatments $\left(50 \mathrm{~kg} \mathrm{~N} \mathrm{ha}^{-1}\right.$ without irrigation). Such rates have been reported for irrigated crops [sunflower and maize, (Skoufogianni et al., 2013)] grown on similar to the study aquic soil. However, in 2011 (lower precipitation, Figure 2), base uptake was somewhat lower, e.g. $57 \mathrm{~N} \mathrm{ha}^{-1}$ for the irrigated treatment, and remained at $36 \mathrm{~kg} \mathrm{~N}^{-1}$ for the rainfed (not irrigated) treatment.

\subsubsection{Recovery Fraction}

Figure 6 shows that N-uptake increases linearly with increasing N-supply above a minimum value represented by base uptake. Fertilization efficiency (recovery fraction) is given by the slope of that line with the horizontal axe. As it is illustrated in Figure 6, soil type and irrigation treatment greatly affect $\mathrm{N}$ recovery fraction. On aquic soils (Palamas), recovery fraction ranges from $15 \%$ to $20 \%$ depending on growing year and irrigation treatment. Such a recovery fraction range is reported in literature (Bransby et al., 1989; Sladden et al., 1994) for switchgrass cultivations with fertilization of $75-180 \mathrm{~kg} \mathrm{~N} \mathrm{ha}^{-1}$. Contrary, in dry soils (Velestino), the recovery fraction remained at low levels (4-6\%) pointing the useless effort of adding any nitrogen in switchgrass growing in such soils. 

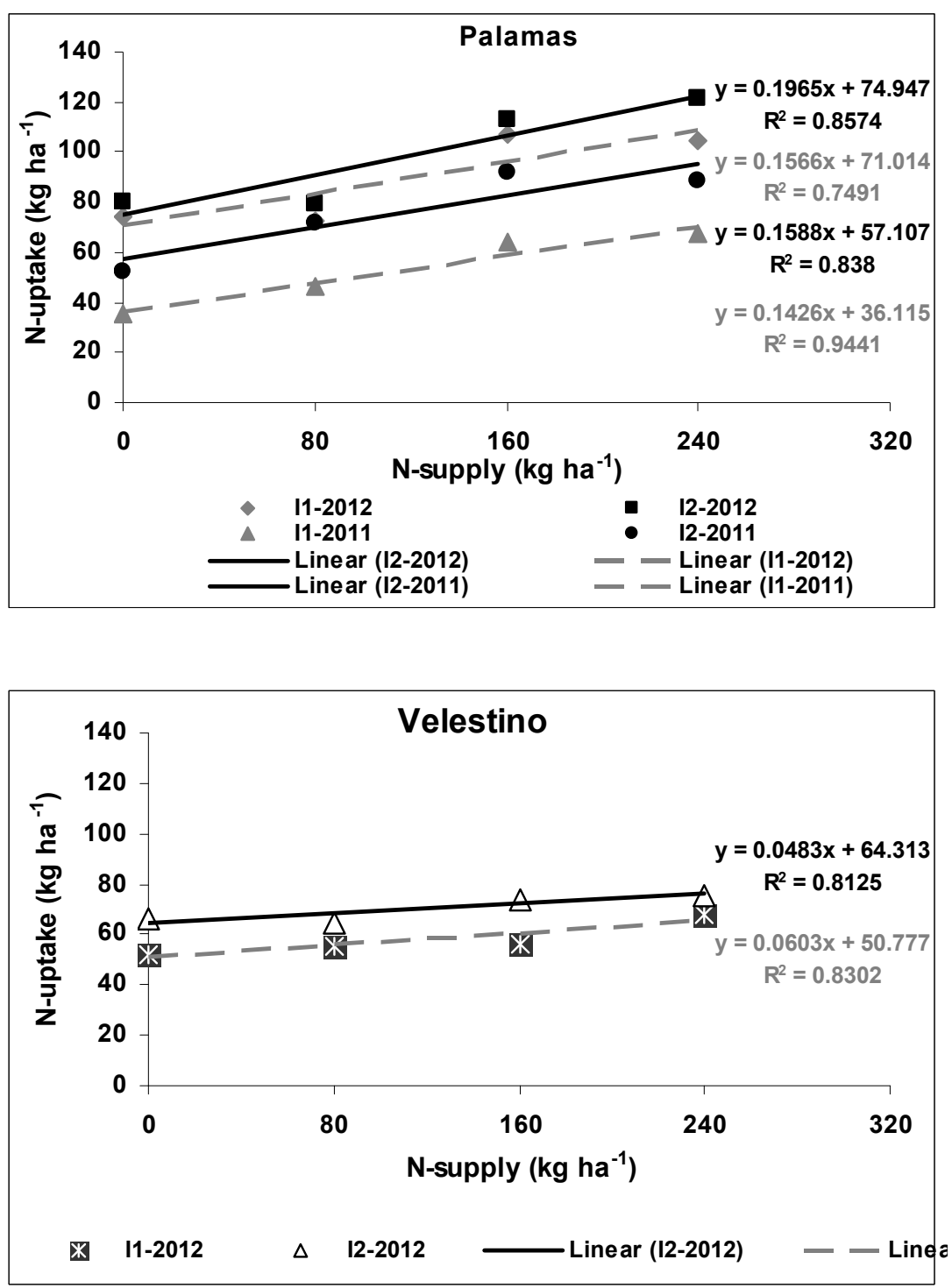

Figure 6. N-uptake $\left(\mathrm{kg} \mathrm{ha}^{-1}\right)$ as affected by $4 \mathrm{~N}$-fertilization levels for 2 irrigations (I1, I2), on 2 different soils (Palamas - aquic, Velestino - dry) during 2 growing periods $(2011,2012)$

Such a low recovery fraction of xeric soils (Velestino) shows that fertilization is obviously problematic considering the environmental issues. On the other hand, taking into account the great NUE of $132 \mathrm{~kg} \mathrm{dm} \mathrm{kg} \mathrm{N}^{-1}$ and the average prices of common $\mathrm{N}$-fertilizers, moderate fertilization of aquic soils cultivated with switchgrass may give high yields and may thus be conditionally advisable for such soils in Mediterranean countries.

\section{Conclusions}

Panicum virgatum (Switchgrass; vs. Alamo) potential fodder production may reach the $14 \mathrm{t} \mathrm{ha}^{-1}$ under Mediterranean environmental conditions (fluctuating year-to-year). Such yields could be attainable only on aquic soils, which however may represent large areas as in the central Greek lowlands. Oppositely, on typical (non-aquic) soils, fodder yields of 9-10 $\mathrm{tha}^{-1}$ may be produced only with supplemental irrigation.

The N-P-K content in plant tissue is variable among plant organs. The average N-concentration in plant tissue varies between $0.4-0.6 \%$ in stems and $1.2-1.4 \%$ in leaves, showing the very low needs in N. P-content varies between $0.13-0.15 \%$ in leaves and $0.07-0.10 \%$ in stems, and K-content fluctuates between $1.3 \%$ and $1.5 \%$.

Switchgrass Yield-nutrient uptake relationships are linear with very high $\mathrm{R}^{2}$ especially for $\mathrm{N}$ and $\mathrm{K}(0.89$ and 0.80 , respectively), pointing to a NUE $=132 \mathrm{~kg} \mathrm{~kg}^{-1}$ and a $\mathrm{KUE}=75 \mathrm{~kg} \mathrm{~kg}^{-1}$ which are rather high in 
comparison with many other traditional or biomass crops and therefore switchgrass might give acceptable fodder yields even in degraded and erosive soils without or with minimum fertilization inputs.

On Mediterranean aquic soils, base uptake may range from 71 to $74 \mathrm{~kg} \mathrm{~N} \mathrm{ha}^{-1}$ leading to fodder yields of $14 \mathrm{t}$ $\mathrm{ha}^{-1}$. On the same soils, recovery fraction of $\mathrm{N}$-fertilization might be $20 \%$ or more, and combined with the high NUE of switchgrass may make advisable conditional nitrogen fertilization for high yields. Contrarily, on typical Mediterranean (xeric) soils, base uptake rate of $60 \mathrm{~kg} \mathrm{~N} \mathrm{ha}^{-1}$ or less may be expected leading to yields of 9-10 t $\mathrm{ha}^{-1}$. On such soils, actual nitrogen recovery fraction might be experimentally determined for making nitrogen fertilization advisable.

As an overall conclusion, switchgrass (vs Alamo) is a very promising perennial crop for fodder production in Greece and similar Mediterranean environments, characterized by high yields under low inputs, and its introduction in land use systems and soils especially with an aquic moisture regime with or without supplemental irrigation should be seriously taken into consideration. The actual base uptake and recovery fraction connected to the particular soil may be greatly helpful for $\mathrm{N}$-fertilizer recommendation.

\section{References}

Abbeddou, S., Rihawi, S., Hess, H. D., Iniguez, L., Mayer, A. C., \& Kreuzer, M. (2011). Nutritional composition of lentil straw, vetch hay, olive leaves, and saltbush leaves and their digestibility as measured in fat-tailed sheep. Small Ruminant Research, 96, 126-135. https://doi.org/10.1016/j.smallrumres.2010.11.017

Aertsens, J., De Nocker, L., \& Gobin, A. (2013). Valuing the carbon sequestration potential for European agriculture. Land Use Policy, 31, 584-594. https://doi.org/10.1016/j.landusepol.2012.09.003

Asbjornsen, H., Hernandez-Santana, V., Liebman, M. Z., Bayala, J., Chen, J., Helmers, M. J., \& Ong, C. K. (2013). Targeting perennial vegetation in agricultural landscapes for enhancing ecosystem services. Renewable Agriculture and Food Systems. Retrieved from http://lib.dr.iastate.edu/abe_eng_pubs/374

Aurangzaib, M. (2015). Developmental morphology, biomass yield and compositional differences among upland and lowland switchgrass (Panicum virgatum L.) ecotypes grown as a bioenergy feedstock crop. Graduate Theses and Dissertations, Iowa State University. Retrieved from http://lib.dr.iastate.edu/cgi/ viewcontent.cgi?article $=5807 \&$ context $=$ etd

Bransby, D. I., Ward, C. Y., Rose, P. A., Sladden, S. E., \& Kee, D. D. (1989). Biomass production from selected herbaceous species in the Southeastern USA. Biomass, 20, 187-97. https://doi.org/10.1016/0144-4565 (89)90059-0

Casler, M. D. (2012). Switchgrass breeding, genetics, and genomics. In A. Monti (Ed.), Switchgrass (pp. 29-53). Springer, London. https://doi.org/10.1007/978-1-4471-2903-5_2

Elbersen, H., Cristian, D., Bassam, N., Sauerbeck, G., Alexopoulou, E., Sharma, N., \& Piscioneri, I. (2004). A management guide for planting and production switchgrass as a biomass crop in Europe. $2^{\text {nd }}$ Conference on Biomass for Energy Industry and Climate Protection, May 10-14, 2004, Rome Italy. Retrieved from http://library.wur.nl/WebQuery/wurpubs/380256

Frank, A. B., Berdahl, J. D., Hanson, J. D., Liebig, M. A., \& Johnson, H. A. (2004). Biomass and carbon partitioning in switchgrass. Crop Science, 44, 1391-1396. https://doi.org/10.2135/cropsci2004.1391

Ibrahim, M., Ayub, M., Maqbool, M. M., Nadeem, S. M., Haq, T., Hussain, S., ... Lauriault, L. M. (2014). Forage yield components of irrigated maize-legume mixtures at varied seed ratios. Field Crops Research, 169, 140-144. https://doi.org/10.1016/j.fcr.2014.08.013

Jones, J. B., \& Case, V. W. (1990). Soil testing and plant analysis (3rd ed., Chapter 15). Soil Science Society of America, SSSA. https://doi.org/10.2136/sssabookser3.3ed.frontmatter

Lemus, R., Brummer, E. C., Burras, C. L., Moore, K. J., Barker, M. F., \& Molstad, N. E. (2008). Effects of nitrogen fertilization on biomass yield and quality in large fields of established switchgrass in southern Iowa, USA. Biomass Bioenergy, 32, 1187-94. https://doi.org/10.1016/j.biombioe.2008.02.016

Liebig, M. A., Johnson, H. A., Hanson, J. D., \& Frank, A. B. (2005). Soil carbon under switchgrass stands and cultivated cropland. Biomass Bioenergy, 28, 347-54. https://doi.org/10.1016/j.biombioe.2004.11.004

Ma, Z., Wood, C. W., \& Brandsby, D. I. (2001). Impact of row spacing, nitrogen rate, and time on carbon partitioning of switchgrass. Biomass and Bioenergy, 20, 413-419. https://doi.org/10.1016/S0961-9534(01) 00008-3 
Ma, Z., Wood, C. W., \& Bransby, D. I. (2000). Carbon dynamics subsequent to establishment of Switchgrass. Biomass and Bioenergy, 18, 93-104. https://doi.org/10.1016/S0961-9534(99)00077-X

McKendry, P. (2002). Energy production from biomass (part 1): Overview of biomass. Bioresource Technology, 83, 37-46. https://doi.org/10.1016/S0960-8524(01)00118-3

McLaughlin, S. B., \& Walsh, M. E. (1998). Evaluating environmental consequences of producing herbaceous crops for bioenergy. Biomass and Bioenergy, 14, 317-324. https://doi.org/10.1016/S0961-9534 (97)10066-6

Moser, L. E., \& Vogel, K. P. (1995). Switchgrass, big bluestem, and indiangrass. In R. F. Barnes, D. A. Miller, C. J. Nelson (Eds.), Forages, Vol. 1: An introduction to grassland agriculture (pp. 409-420). Ames, IA: Iowa State University. https://doi.org/10.1017/S0021859600073226

Muir, J. P., Sanderson, M. A., Ocumpaugh, W. R., Jones, R. M., \& Reed, R. L. (2001). Biomass production of 'Alamo' switchgrass in response to nitrogen, phosphorus, and row spacing. Agronomy J., 93, 896-901. https://doi.org/10.2134/agronj2001.934896x

National Research Council. (1996). Nutrient Requirements of Beef Cattle (7th ed.). National Academy Press, Washington.

Nelson, D. W., \& Sommers, L. E. (1973). Determination of total nitrogen in plant material. Agronomy J., 65, 109-12. https://doi.org/10.2134/agronj1973.00021962006500010033x

Piscioneri, L., Pignatelli, V., Palazzo, S., \& Sharma, N. (2001). Switchgrass production and establishment in the Southern Italy climatic conditions. Energy Conversion and Management, 42, 2071-82. https://doi.org/ 10.1016/S0196-8904(00)00174-6

Sanderson, M. A., Brink, G. E., Higgins, K. F., \& Naugle, D. E. (2004). Chapter 11: Alternative uses of warm-season forage grasses. In L. Moser, B. Burson, \& L. Sollenberger (Eds.), Wam-Season Grasses. American Society of Agronomy Monograph Series (Vol. 45, pp. 389-416).

Skoufogianni, E., Danalatos, N. G., Dimoyiannis, D., \& Efthimiadis P. (2013). Effects of Pea Cultivation as cover Crop on Nitrogen-Use Efficiency and Nitrogen Uptake by Subsequent Maize and Sunflower Crops in a sandy Soil in Central Greece. Communication in Soil Science and plant Analysis, 44(1-4), 861-868. https://doi.org/10.1080/00103624.2013.749446

Sladden, S. E., Bransby, D. I., \& Kee, D. D. (1994). Changes in yield and forage quality with time for two switchgrass varieties. Proceedings of American Forage and Grassland Council, 3, 242-246.

Thomason, W. E., Raun, W. R., \& Johnson, G. V. (2000). Winter Wheat Nitrogen Use Efficiency in Grain and Forage Production Systems. Journal Plant Nutrition, 23, 1505-1516. https://doi.org/10.1080/0190416000 9382118

Tie-jun, Z., Jun-mei, K., Wen-shan, G., Zhong-xiang, Z., Yu-peng, X., Xudong, Y., \& Qing-chuan, Y. (2014). Yield Evaluation of Twenty-Eight Alfalfa Cultivars in Hebei Province of China. Journal of Integrative Agriculture, 13(10), 2260-2267. https://doi.org/10.1016/S2095-3119(13)60576-6

Tolbert, V. R., \& Wright, L. L. (1998). Environmental enhancement of US biomass crop technologies: Research results to date. Biomass and Bioenergy, 15, 93-100. https://doi.org/10.1016/S0961-9534(98)00005-1

USDA (Soil Survey Staff). (1975). Soil taxonomy. Basic system of soil classification for making and interpreting soil surveys. Agricultural handbook (Vol. 466, p. 754). Washington, DC: USDA.

Vadiveloo, J. (2000). Nutritional properties of the leaf and stem of rice straw. Animal Feed Science and Technology, 83, 57-65. https://doi.org/10.1016/S0377-8401(99)00107-8

West, D. R., \& Kincer, D. R. (2011). Yield of switchgrass as affected by seeding rates and dates. Biomass Bioenergy, 35, 4057-4059. https://doi.org/10.1016/j.biombioe.2011.06.048

\section{Copyrights}

Copyright for this article is retained by the author(s), with first publication rights granted to the journal.

This is an open-access article distributed under the terms and conditions of the Creative Commons Attribution license (http://creativecommons.org/licenses/by/4.0/). 